\title{
İskemik ve Hemorajik İnme Hastalarında Kan Lipid Parametrelerinin Karşılaştırılması ve Mortalite ile İlişkisi
}

\section{Comparison of Blood Lipid Parameters in Patients with Ischemic and Hemorrhagic Stroke and Its Relationship with Mortality}

\author{
Fettah Eren ${ }^{1}$, Kamile Yücel ${ }^{2}$ \\ ${ }^{1}$ Selçuk Üniversitesi, Tip Fakültesi, Nöroloji A.D., Konya, Türkiye \\ ${ }^{2}$ KTO Karatay Üniversitesi, Sağlık Bilimleri Yüksek Okulu, Tibbi Biyokimya, Konya Türkiye \\ Yazıșma Adresi / Correspondence: \\ Kamile Yücel \\ KTO Karatay Üniversitesi, Sağllk Bilimleri Yüksek Okulu, Konya \\ T: +9050577998 $83 \quad$ E-mail: kamile_yucel@hotmail.com \\ Geliş Tarihi / Received : 29.12.2020 Kabul Tarihi / Accepted : 11.06.2021 \\ Orcid: \\ Kamile Yücel https://orcid.org/0000-0003-4088-8932 \\ Fettah Eren https://orcid.org/0000-0001-6834-0827 \\ ( Sakarya Tip Dergisi / Sakarya Med J 2021, 11(2):400-408) DOI: 10.31832 smj.849225
}

\footnotetext{
Öz

Amaç Çalıșmada iskemik ve hemorajik inme hastalarında kan lipid parametrelerinin değerlendirilmesi ve mortalite ile ilişkisinin incelenmesi amaçlanmıștır.

Gereç ve Retrospektif özellikte, kesitsel ve hastane temelli klinik bir çalısma olarak planlandı. İskemik ve hemorajik inme tanısı klinik bulgular, beyin difüzyon ağırlıklı manyetik Yöntem rezonans görüntüleme (MRG) ve bilgisayarlı tomografi (BT) ile konfirme edildi. Hastane içi inme mortalite oranları hesaplandı. Hastaların serum lipid profili (trigliserid, total kolesterol, yüksek dansiteli lipoprotein (HDL) kolesterol ve düşük dansiteli lipoprotein (LDL) kolesterol) incelendi.

Bulgular Çalıșmada 60 iskemik ve 50 hemorajik inme hastası dahil edildi. İskemik ve hemorajik inme gruplarında diyabetes mellitüs (DM) ve koroner arter hastalığı (KAH) sıklığı benzerdi (sırasıla p: 0,649, p: 0,919). Hipertansiyon hemorajik inme grubunda daha sıktı (p: 0,006). Mortalite oranları iskemik inmede \%10 (n: 6), hemorajik inmede \%36 (n: 18) idi. İskemik inme ve hemorajik inmede serum lipid seviyeleri karşılaștırıldı̆̆ında, total kolesterol iskemik inme grubunda yüksekti (p: 0,003). Trigliserit, HDI ve LDL kolesterol seviyesi benzerdi (sırasiyla, p: 0,929, p: 0,443, p: 0,133). Mortalite ile seyreden tüm inme hastalarında serum trigliserid ve total kolesterol seviyesi daha düșüktü ( $\mathrm{p}=0,047, \mathrm{p}=0,002)$. Diğer parametreler benzerdi.

Sonuç Calıșmamızda serum total kolesterol seviyesi iskemik inme hastalarında daha yüksektir. Hipertansiyon hemorajik inmede daha sıktır. Trigliserit ve total kolesterol düșüklüğü inme hastalarında kısa dönem mortalite ile ilișkilidir.

Anahtar Hemorajik inme; iskemik inme; lipidler; prognoz; risk faktörleri

Kelimeler
}

Abstract

Objective The aim of this study is to evaluate blood lipid parameters in patients with ischemic and hemorrhagic stroke and its relationship with mortality.

Materials For the study, patients with acute ischemic stroke and hemorrhagic stroke who received inpatient treatment in the neurology clinic between January 2017 and October 2020 were retrospectively analyzed. In-hospital ischemic and hemorrhagic stroke mortality rates were calculated. The lipid profile of the patients (triglyceride, total cholesterol, HDL cholesterol and LDL cholesterol) was evaluated with blood samples taken after 12 hours of fasting.

Results There were 60 ischemic and 50 hemorrhagic stroke patients in the study. The frequency of diabetes mellitus (DM) and coronary artery disease (CAD) were similar in groups with ischemic and hemorrhagic stroke (p: 0,649, p: 0,919, respectively). Hypertension was higher in the hemorrhagic stroke group (p: 0,006). Mortality rates were 10\% (n: 6) in ischemic stroke and 36\% (n: 18) in hemorrhagic stroke. Comparison of serum lipid levels in ischemic stroke and hemorrhagic stroke; Total cholesterol was higher in ischemic stroke group (p: 0,003). Triglyceride, HDL, and LDL cholesterol levels were similar in groups ( $p: 0,929, p: 0,443, p: 0,133$, respectively). Serum triglyceride and total cholesterol levels were lower in all stroke patients with mortality ( $p: 0,047$, p: 0,002). Other parameters were similar.

Conclusion Serum total cholesterol level is higher in patients with ischemic stroke. Hypertension is more common in hemorrhagic stroke. Low triglycerides and low total cholesterol are associated with short-term mortality in patients with stroke.

Keywords Hemorrhagic stroke; ischemic stroke; lipids; prognosis; risk factors 


\section{GIIRIŞ}

İnme, beynin bir bölgesinin iskemi veya kanama sonucu kalıcı ya da geçici olarak etkilenmesiyle ortaya çıkan, dizabilite ve mortalite oranları yüksek ciddi bir hastalıktır., İnme etyolojisine göre yapılan sınıflandırmalar iskemik ve hemorajik olmak üzere 2 sınıfa ayrılır. Batı toplumlarında inmenin yaklaşı $\% 85$ 'i iskemi, \%15'i hemoraji nedeniyle meydana gelmektedir. ${ }^{2-4}$ Ülkemizde ise yapılan çok merkezli çalışmada iskemik inmenin \%72, hemorajik inmenin \%28 oranda görüldügü bildirilmiştir. ${ }^{5}$ İskemik inme, fokal, serebral, spinal veya retinal iskemi sonucu gelişen nörolojik disfonksiyon durumudur. Hemorajik inme ise vasküler bir olay sonucu arteriyel veya venöz kanın ani olarak beyin dokusu içine geçişi ile ortaya çıkan klinik tablodur. Tüm inmeler içinde iskemik inmelerden daha az görülmesine karşın daha mortal seyrettiği bilinmektedir. Bu durum, damar dışına çıkan kan miktarı, hematomun kitle etkisi, yaygınlığı ve lokalizasyonu ile yakından ilgili olup ölüm oranı \%25- 60 arasında değişir. ${ }^{6-9}$

İnme için risk faktörlerini inceleyen epidemiyolojik çalışmalarda yaş, cinsiyet, aile öyküsü ve genetik faktörler değiştirilemeyen risk faktörleri arasında, hipertansiyon (HT), diyabetes mellitüs (DM), kalp-damar hastalıkları, ateroskleroz, obezite, sigara ve alkol kullanımı ise değiştirilebilir risk faktörleri arasında yer almaktadır. İnme insidansının düşürülmesinde, değiştirilebilir risk faktörlerinin önlenmesi ve azaltılması çok önemlidir. ${ }^{10-12}$

İnme riski yaşla birlikte artmakta, erkeklerde ve siyah ırkta daha fazla görülmektedir. ${ }^{13,14}$ Sigara kullanımını ve aşırı alkol alımını kuvvetli risk faktörleri arasında gösteren güçlü kanıtlar vardır. Bunlar diğer risk faktörlerinin etkisini de (özellikle düşük dansiteli lipoprotein (LDL) oksidasyonu) arttırabilmektedir. ${ }^{13,15}$ Risk faktörlerinden DM, ateroskleroza karşı oluşan duyarlılığı arttırarak mortalite ve morbiditeyi arttırmaktadır. ${ }^{16,17}$ Hipertansiyon ise hem iskemik hem de hemorajik inme için düzeltilebilir major risk faktörleri arasındadır. Prevalansının çok sık olması ve tedavi edilmesi halinde inme riskini azaltması açısından hipertansiyon değiştirilebilen önemli risk faktörüdür. ${ }^{10,18,19}$ Ateroskleroz, sinsice ilerleyen, immüno-inflamatuvar bir hastalıktır. Miyokard infarktüsü ve inme aterosklerozun en kötü sonuçları arasındadır. Serum yüksek dansiteli lipoprotein (HDL) kolesterol düzeyi iskemik inme arasındaki ters korelasyon gösterilmiştir. Artmış plazma LDL kolesterol konsantrasyonu ve azalmış HDL kolesterol konsantrasyonu ateroskleroz gelişiminde primer risk faktörüdür. Tersine hemorajik inme azalmış serum kolesterol düzeyi ile ilişkilendirilmiştir. ${ }^{20-23}$

Bu bilgiler 1şı̆̆ında, iskemik inme ve hemorajik inme hastalarının, eşlik eden hastalıklarını ve kan lipid parametrelerini karşılaştırmayı, bu durumun mortalite ile ilişkisini ortaya koymayı amaçladık.

\section{GEREÇ ve YÖNTEMLER}

Çalışma hastane temelli, kesitsel ve retrospektif özellikte klinik bir araştırmadır. Ocak 2017- Ekim 2020 tarihleri arasında nöroloji kliniğinde yatarak tedavi alan inme hastaları incelendi. Hastalarda klinik ve nöro-radyolojik değerlendirme yapıldı. Klinik ve nörolojik muayenede bilinç durumu, kas gücü, duyusal, görsel, serebellar semptomlar ve kraniyal sinir bulguları incelendi. İskemik inme tanısı klinik özellikler ve başvuru semptomları yanında difüzyon manyetik rezonans görüntüleme (MRG) ile konfirme edildi. Hemorajik inme tanısı ise acil serviste hastaneye ilk başvuru sırasında çekilen bilgisayarlı beyin tomografisi (BBT) ile ortaya konuldu. Hastalar iskemik inme ve hemorajik inme olarak 2 gruba ayrıldı. Anterior ve/veya posterior serebral bölge lokalizasyonundaki iskemi ve hemoraji durumu klinik ve nöro-görüntüleme tetkikleri ile birlikte değerlendirildi. Hastalar inme lokalizasyonuna göre de 2 gruba (anterior ve/veya posterior) ayrıldı. İskemik inme nedeni ile intravenöz trombolitik tedavi ve nörovasküler girişimsel tedaviler uygulanan hastalar da çalışmaya alınmadı. Hastalarda başvuru anındaki kronik hastalıkları (HT, DM, KAH), sigara ve alkol bağımlılık durumları hasta ve/veya hasta yakınından alınan bilgiler ve kullanmakta olduğu tedaviler değerlendirilerek ortaya konuldu. Hiper- 
lipidemi özgeçmişi olan, başvuruda veya öncesinde anti-hiperlipidemik tedavi alan hastalar çalışmaya alınmadı. Hastaların kan lipid değerleri (trigliserid, total kolesterol, LDL kolesterol ve HDL kolesterol) 12 saat açlik sonrası, saat 5:00-08:00 arası alınan kan örnekleri ile incelendi. Kan örnekleri hastaların yatışından sonraki gün antebrakial ven yolu ile elde edildi. Hastane süreci sırasında takiplerinde eksitus nedeni ile kaybedilenler ve taburcu edilen hastalar 2 gruba ayrılarak primer sonlanım noktası olarak kabul edildi. Hastane içi mortalite oranı $=$ [iskemik veya hemorajik inme nedeni ile hastanede yatış sürecinde ex olan hastalar/bu tanılar ile hastanede yatarak tedavi alan hastalar) x 100] formülü kullanılarak hesaplandı.

Çalışma için KTO Karatay Üniversitesi, Tıp Fakültesi İlaç ve Tıbbi Cihaz Dışı Araştırmalar Etik Kurul Başkanlığı’ndan onay alındı (Sayı: 2020/009, Tarih: 15.12.2020).

\section{İstatistiksel Analiz}

Veri toplama aşaması sonunda elde edilen veriler bilgisayar ortamına aktarılarak analiz edildi. Analiz için SPSS for Windows version 15.0 (SPSS Inc., Chicago, IL, USA) paket programı kullanıldı. Verilerin normal dağılıma uygunluğu görsel (histogram ve olasılık grafikleri) ve analitik yöntemler (Kolmogrorov-Smirnov/Shapiro-Wilk testleri) kullanılarak incelendi. Sayısal verilerin özetlenmesinde; aritmetik ortalama, standart sapma, minimum ve maximum değerleri, kategorik verilerin özetlenmesinde frekans dağılımları ve yüzdelikler kullanıldı. Kategorik verilerin karşılaştırılmasında ki-kare testi veya Fisher testi kullanıldi. Sayısal verilerle grup ve cinsiyet değişkenleri arasındaki ilişki Student- T ve Man-Whitney U testleri ile değerlendirildi. Sayısal verilerin korelasyonları Spearman korelasyon katsayısı ile analiz edildi. Prognoz üzerine kategorik verilerin etkisini incelemek için binary lojistik regresyon analizi kullanıldı. Model uyumu için Hosmer - Lemeshov testi kullanıldı. Değişkenin bağımlı değişken üzerine ortak etkisini ölçmek için iki-yönlü varyans analizi kullanıldı. ROC analizi sonucu eğri altında kalan alan (AUC) olarak verildi. İstatistiksel anlamlılık için tip-1 hata düzeyi \%5 olarak kabul edildi.

\section{BULGULAR}

Çalışmaya iskemik inme (n: 60) ve hemorajik inme (n: 50) tanısı ile takip ediilen 110 hasta dahil edildi. Çalışmada 36-93 yaş arasında 48 kadın ve 62 erkek hasta vardı ve hastaların \%55'i 65 yaş üzerindeydi. Gruplar arasında yaş ortalamas1 $(z=-1,192, p: 0,233)$ ve cinsiyet $(X 2=0,005, p$ : $0,944)$ açısından anlamlı bir fark yoktu. 27 hastada sigara ve 7 hastada alkol kullanımı vardı. İskemik inme grubunda 15 (\%25) DM, $16(\% 26,6)$ HT, 8 (\%13,3) KAH yer alırken, hemorajik inme grubunda 10 (\%20) DM, 24 (\%54) HT, 7 (\%14) KAH vardı. Gruplar arasında DM ve KAH sıklığı açısından fark bulunmazken, HT hemoraijk inme grubunda daha sıkt1 (sırasiyla, X2 =0,388, p: 0,649, X2 = 0,010, p: 0,919, X2=8,558, p: 0,006). Grupların temel karakteristikleri Tablo 1' de verildi.

Hastaların prognozuna bakıldı̆̆ında 110 hastadan 86'sı eksterne edilmiş olup, 24 hasta ise exitus nedeniyle kaybedildi. İskemik inme grubunda 6, hemorajik inme grubunda ise 18 hasta ex oldu. Hastane içi mortalite oranı iskemik inmede $\% 10$, hemorajik inmede ise $\% 36$ olarak hesaplandı. Hastalar taburcu ve exitus durumlarına göre değerlendirildiğinde yaş, LDL kolesterol, HDL kolesterol açısından gruplararası anlamlı fark yoktu (sırasıly, p: 0,347, p: 0,068, p: 0,893). Trigliserit ve total klesterol mortal seyreden hasta grubunda daha düşüktü (sırasıyla, p: 0,047, p: 0,002). Hastaların prognoz durumuna göre ayrıntılı kan lipid değerleri Tablo 2. de özetlendi.

Prognoz üzerinde inme tipi, HT varlığı, cinsiyet, DM varlığı, KAH varlığı, sigara, alkol kullanımının etkilerini incelemek için binary lojistik reg kullanıldı. Model uyumu iyiydi ve Hosmer lemeshov test sonucu 0.866 olarak bulundu. Prognoz üzerinde inme tipi ( $\mathrm{p}=0,000$ ) ve HT ( $\mathrm{p}=0,032)$ etkisi anlamlı bulundu. Hemorojik inme 7,388, HT varlığı 3,326 kat mortalite riski oluşturmaktaydı (Tablo 3). 
Sakarya Tip Dergisi 2021;11(2):400-408

EREN ve Ark., İnme ve Lipid Parametreleri

Tablo 1. İskemik ve hemorajik inme gruplarının demografik özellikleri

\begin{tabular}{|c|c|c|c|c|c|}
\hline Değiş̧kenler & $\begin{array}{l}\text { Toplam } \\
\text { (n: 110) }\end{array}$ & $\begin{array}{c}\text { İskemik inme } \\
(\text { ort } \pm S S)(n: 60)\end{array}$ & $\begin{array}{l}\text { Hemorajik inme } \\
(\text { ort } \pm \text { SS) (n: 50) }\end{array}$ & $\underset{\text { değeri }}{p}$ & $\mathrm{X}^{2}$ \\
\hline Yaş ortalaması & $64,31 \pm 15,18$ & $65,73 \pm 15,86$ & $62,62 \pm 14,29$ & 0,233 & \\
\hline $\begin{array}{l}\text { Cinsiyet (Kadın/ } \\
\text { Erkek) }\end{array}$ & $48 / 62$ & $26 / 34$ & $22 / 28$ & 0,944 & 0,005 \\
\hline Sigara (V/Y) & $27 / 83$ & $17 / 43$ & $10 / 40$ & 0,377 & 1,023 \\
\hline Alkol (V/Y) & $7 / 103$ & $2 / 58$ & $5 / 45$ & - & - \\
\hline $\mathrm{DM}(\mathrm{V} / \mathrm{Y})$ & $25 / 85$ & $15 / 45$ & $10 / 40$ & 0,649 & 0,388 \\
\hline $\mathrm{HT}(\mathrm{V} / \mathrm{Y})$ & $43 / 67$ & $16 / 44$ & $27 / 23$ & $0,006^{*}$ & 8,558 \\
\hline $\mathrm{KAH}(\mathrm{V} / \mathrm{Y})$ & $15 / 95$ & $8 / 52$ & $7 / 43$ & 0,919 & 0,010 \\
\hline Prognoz (E/T) & $24 / 86$ & $6 / 54$ & $18 / 32$ & $0,001^{*}$ & 10,808 \\
\hline
\end{tabular}

n: Olgu sayısı, SS: Standart sapma, V: Var, Y: Yok, DM: Diyabetes mellitus, HT: Hipertansiyon, KAH: Koroner arter hastalığı, E: Exitus, T:

Taburcu, -: sayı az olduğu için istatistiksel kıyaslamaya uygun değil, ${ }^{*} \mathrm{p}<0,05$ istatistiksel anlamlı

Tablo 2. İskemik ve hemorajik inme hastalarında kısa dönem prognoz ile kan lipid parametleri arasındaki ilişki

\begin{tabular}{|l|c|c|c|c|c|}
\hline \multirow{2}{*}{ Değişkenler } & \multicolumn{2}{|c|}{ İskemik inme } & \multicolumn{3}{c|}{ Hemorajik inme } \\
\cline { 2 - 6 } & Eksitus (6) & Taburcu (54) & Eksitus (18) & Taburcu (32) \\
\hline Yaş & $74,66 \pm 11,32$ & $64,74 \pm 16,006$ & $64,27 \pm 16,25$ & $61,68 \pm 13,24$ & 0,354 \\
\hline Trigliserit (mg/dL) & $125,66 \pm 57,32$ & $121,90 \pm 62,59$ & $91,50 \pm 31,79$ & $141,25 \pm 66,41$ \\
\hline Total kolesterol (mg/dL) & $158,83 \pm 33,31$ & $174,29 \pm 42,55$ & $137,94 \pm 26,96$ & $159,78 \pm 30,47$ & 0,089 \\
\hline LDL kolesterol (mg/dL) & $98,30 \pm 31,42$ & $110,30 \pm 38,16$ & $90,56 \pm 26,19$ & $103,47 \pm 34,58$ \\
\hline HDL Kolesterol (mg/dL) & $36,66 \pm 6,47$ & $39,31 \pm 8,64$ & $40,50 \pm 7,80$ & $39,40 \pm 6,31$ \\
\hline LDL: Düşük yoğunluklu lipoprotein, HDL: Yüksek yoğunluklu lipoprotein, ${ }^{*} \mathrm{p}<0,05$ istatistiksel anlaml & 0,960 \\
\hline
\end{tabular}

Tablo 3. Binary lojistik regresyon modeline göre prognozla ilişkili değişkenler

\begin{tabular}{|c|c|c|c|c|c|c|c|}
\hline & \multirow{2}{*}{$\beta$} & \multirow{2}{*}{ S.E. } & \multirow{2}{*}{ Wald } & \multirow{2}{*}{ Sig. } & \multirow{2}{*}{$\operatorname{Exp}(B)$} & \multicolumn{2}{|c|}{ 95\% C.I.for EXP (B) } \\
\hline & & & & & & Lower & Upper \\
\hline İskemik-hemorajik inme & 2,00 & 0,565 & 12,534 & 0,000 & 0,233 & 2,442 & 22,355 \\
\hline Hipertansiyon varlığı & 1,202 & 0,561 & 4,590 & 0,032 & 3,326 & 1,108 & 9,986 \\
\hline
\end{tabular}

İskemi lokalizayonları ise 91 adet anterior vasküler alan, 15 adet posterior vasküler alan ve 4 adet anterior-posterior vasküler alan şeklindeydi. İskemi lokalizasyonuna göre lipid parametreleri açısından gruplar arasında yapılan k1yaslamada anlamlı bir fark yoktu $(\mathrm{p}>0,05)$.

Lipid parametreleri açısından gruplar karşılaştırıldığında; iskemik inme ve hemorajik inme grupları arasında total kolesterolün iskemik inme grubunda yüksek olmasından kaynaklı anlamlı fark elde edilirken (p: 0,003), trigliserit, HDL kolesterol ve LDL kolesterol açısından gruplar arası anlamlı bir fark yoktu (sırasiyla, p: 0,929, p: 0,443, p: 0,133). Grupların lipid profilleri açısından karşılaştırılma- s1 Tablo 4'te verildi.

Lipid parametreleri açısından korelasyonlar incelendiğinde iskemik inme ve hemorajik inme grubunda trigliserit ve HDL arasinda negatif korelasyon (sirasiyla, $r=-0,479$, $\mathrm{p}=0,000, \mathrm{r}=-0,439, \mathrm{p}=0,001)$, total kolesterol ve LDL arasında ise iskemik inmede güçlü pozitif korelasyon, hemorajik inmede orta derece güçlü pozitif korelasyon görüldü (sirasiyla, $r=0,877, p=0,000, r=0,646, p=0,000)$. LDL klesterol ve trigliserit arasında her iki grupta da anlamlı bir korelasyon görülmedi. Grupların lipid profilleri açısından korelasyon sonuçları Tablo 5'te, total kolesterol ve LDL kolesterol korelasyon grafikleri ise Şekil 1 ve 2'de verildi. 
Sakarya Tip Dergisi 2021;11(2):400-408

EREN ve Ark., İnme ve Lipid Parametreleri

Tablo 4. İskemik ve hemorajik inme gruplarının lipid profili açısından karşılaştırılması

\begin{tabular}{|l|c|c|c|}
\hline Değişkenler & $\begin{array}{c}\text { İskemik inme } \\
\text { (ort } \pm \text { SS) (n: 60) }\end{array}$ & $\begin{array}{c}\text { Hemorajik inme } \\
\text { (ort } \pm \text { SS) (n: 50) }\end{array}$ & p \\
\hline Trigliserit (mg/dL) & $122,28 \pm 61,63$ & $123,34 \pm 61,02$ & 0,929 \\
\hline Total kolesterol (mg/dL) & $172,75 \pm 41,74$ & $151,92 \pm 30,85$ & $0,003^{*}$ \\
\hline HDL kolesterol (mg/dL) & $39,05 \pm 8,44$ & $39,80 \pm 6,83$ & 0,443 \\
\hline LDL kolesterol (mg/dL) & $109,10 \pm 37,48$ & $98,83 \pm 32,15$ & 0,133 \\
\hline n: Olgu sayısı, SS: Standart sapma, LDL: Düșük yoğunluklu lipoprotein, HDL: Yüksek yoğunluklu lipoprotein, ${ }^{*} \mathrm{p}<0,05$ istatistiksel anlamlı \\
\hline
\end{tabular}

Tablo 5. İskemik ve hemorajik inme gruplarının lipid profilleri açısından korelasyon sonuçları

\begin{tabular}{|c|c|c|c|c|c|}
\hline Gruplar & & Trigliserit & Total kolesterol & HDL kolesterol & LDL kolesterol \\
\hline \multirow{8}{*}{ İskemik İnme } & \multirow{2}{*}{ Trigliserit } & \multirow{2}{*}{-} & $\mathrm{r}=0,392$ & $r=-0,479$ & $r=0,219$ \\
\hline & & & $\mathrm{p}=0,002$ & $\mathrm{p}=0,000$ & $\mathrm{p}=0,092$ \\
\hline & \multirow{2}{*}{ Total kolesterol } & $r=0,392$ & \multirow{2}{*}{-} & $r=0,195$ & $\mathrm{r}=0,877^{\star *}$ \\
\hline & & $\mathrm{p}=0,002$ & & $\mathrm{p}=0,136$ & $\mathrm{p}=0,000$ \\
\hline & \multirow{2}{*}{ HDL kolesterol } & $r=-0,479$ & $\mathrm{r}=0,195$ & \multirow{2}{*}{ - } & $r=0,229$ \\
\hline & & $\mathrm{p}=0,000$ & $\mathrm{p}=0,136$ & & $\mathrm{p}=0,079$ \\
\hline & \multirow{2}{*}{ LDL kolesterol } & $\mathrm{r}=0,219$ & $\mathrm{r}=0,877^{\star *}$ & $r=0,229$ & \multirow{2}{*}{-} \\
\hline & & $\mathrm{p}=0,092$ & $\mathrm{p}=0,000$ & $\mathrm{p}=0,079$ & \\
\hline \multirow{8}{*}{ Hemorajik inme } & \multirow{2}{*}{ Trigliserit } & \multirow{2}{*}{-} & $\mathrm{r}=0,235$ & $r=-0,439$ & $r=-0,132$ \\
\hline & & & $\mathrm{p}=0,100$ & $\mathrm{p}=0,001$ & $\mathrm{p}=0,361$ \\
\hline & \multirow{2}{*}{ Total kolesterol } & $r=0,235$ & \multirow{2}{*}{-} & $r=0,169$ & $r=0,646^{*}$ \\
\hline & & $\mathrm{p}=0,100$ & & $\mathrm{p}=0,240$ & $\mathrm{p}=0,000$ \\
\hline & \multirow{2}{*}{ HDL kolesterol } & $r=-0,439$ & $\mathrm{r}=0,169$ & \multirow{2}{*}{-} & $\mathrm{r}=0,330$ \\
\hline & & $\mathrm{p}=0,001$ & $\mathrm{p}=0,240$ & & $\mathrm{p}=0,019$ \\
\hline & \multirow{2}{*}{ LDL kolesterol } & $\mathrm{r}=-0,132$ & $r=0,646^{*}$ & $r=0,330$ & \multirow{2}{*}{ - } \\
\hline & & $\mathrm{p}=0,361$ & $\mathrm{p}=0,000$ & $\mathrm{p}=0,019$ & \\
\hline
\end{tabular}


Yapılan ROC analizinde eğri altında kalan alan trigliserit, total kolesterol, LDL ve HDL kolesterol için sirasıyla 0,487, $0,668,0,583$ ve 0,458 olarak bulundu ve sadece kolesterol için anlamlı fark elde edildi (p:0,002). Total kolesterol için ROC grafiği Şekil 3’te verildi.

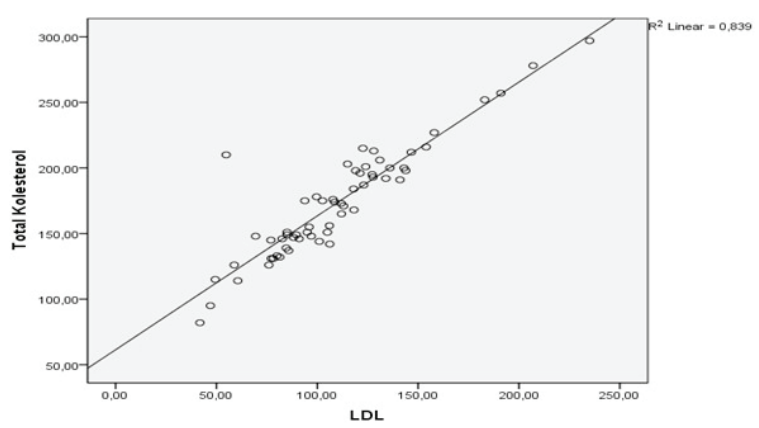

Şekil 1. Ískemik inme grubunda total kolesterol-LDL kolesterol korelasyon grafiği

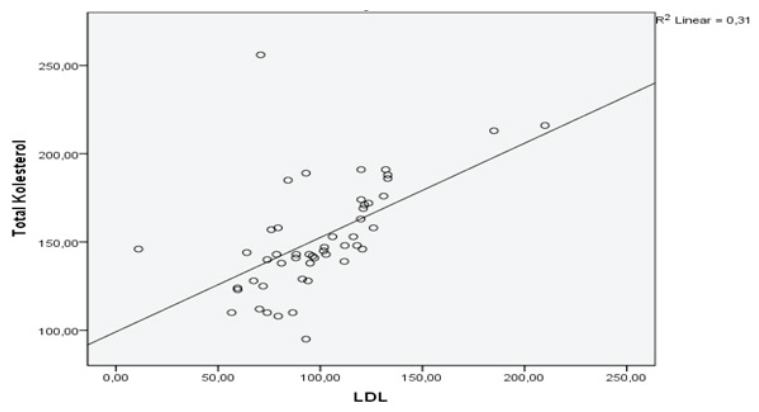

Şekil 2. Hemorajik inme grubunda total kolesterol-LDL kolesterol korelasyon grafiği

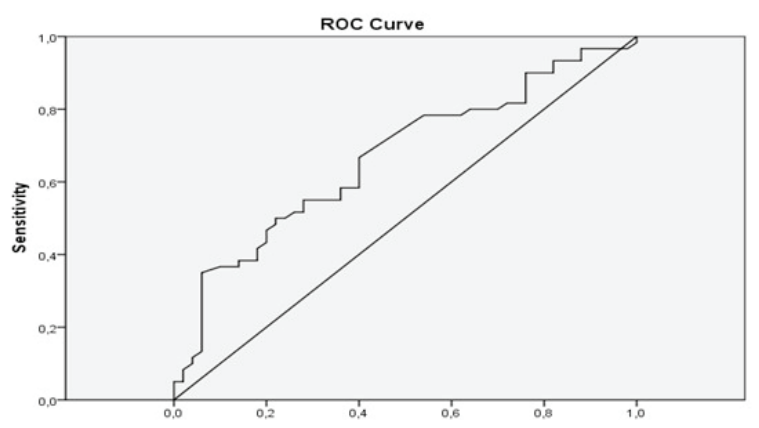

Şekil 3: Total kolesterole ait ROC analiz grafiği

\section{TARTIŞMA}

İnme nörolojik hastalıklar içinde oldukça sık görülen ciddi bir halk sağlığı problemidir ve yaşla birlikte artış gösterir. Erkeklerde kadınlara oranla fazla görülmektedir. Mevcut çalışmamızda iskemik inme grubunda yaş ortalaması $65,73 \pm 15,86$, hemorajik inme grubunda $62,62 \pm 14,29$ idi. Çalışmamızda hem iskemik hem de hemorajik inme grubunda erkek hasta sayısı kadın hasta sayısından fazla bulundu. Toplumların kendine ait özellikleri inme yaş ortalamasını ve cinsiyet farklılıklarını etkilese de sonuçlarımız diğer çalışmalarla uyumludur. ${ }^{8,9,11}$ Sigara içmenin inme riskini arttırdığı özellikle hemorajik inmeyi arttırdığını belirten çalışmalar bulunmaktadır. Alkol tüketimi ise HT ve hiperkoagülabilite durumuna yol açtığı için inme riskini de arttırmaktadır. ${ }^{11-14}$ Bizim çalışmamızda ise iskemik inmede sigara içme oranı hemorajik inmeye göre daha fazla olsa da sigara ve alkol kullanımı açısından gruplar arasında anlamlı fark yoktu. Ancak çalışmamızda kontrol grubu olmadığı için genel popülasyonla karşılaştırma yapılmamıştır.

İnme etyolojisinin araştırıldığı çalışmalar, eşlik eden hastalıklar açısından hastalarda DM ve HT’nin ciddi risk faktörleri arasında olduğunu göstermektedir. DM'nin inme riskini 1-3 kat arasında arttırdığ bildirilmiştir. Kuusisto ve ark. 3,5 y1l boyunca diyabeti olan 229 ve diyabeti olmayan 1298 kişiyi takip etmişler ve diyabetlilerde inme oranını $\%$ 6,1, diyabeti olmayanlarda da \%3,4 olarak bildirmişlerdir. ${ }^{24}$ Bazı çalışmalar, özellikle iskemik inme grubunda DM ve HT oranını yüksek bulmuştur. ${ }^{6,7}$ Çalışmamızda diyabet ve HT açısından risk faktörleri incelendiğinde iskemik inme grubunda DM (\%25), hemorajik inme grubunda ise HT (\% 54) fazla bulunmuştur, fakat gruplararası DM açısından farklılık anlamlı değilken, HT açısından anlamlı fark elde edilmiştir. Bazı çalışmalar, hipergliseminin ve DM’nin inme hastalarında prognozu kötüleştirdiğini vurgulamıştır. ${ }^{6,816}$ Snarska ve arkadaşları 2015 yılında iskemik ve hemoraik inmeli 766 hastayla gerçekleştirdikleri çalışmada exitus görülen hastaların kan glukoz değerinin, exitus görülmeyenlere göre oldukça yüksek olduğunu 
$(\mathrm{p}<0.001)$ ve hipergliseminin kötüleşen klinik durumla korele olduğunu belirtmişlerdir. ${ }^{25}$ Literatürde inme görülen hastalarda exitus oranı \%12,7-33 arasında değişmektedir. Bizim çalışmamızda bu oran \%27 idi. Hemorajik inme grubunda iskemik inme grubuna göre exitus oranı daha fazlayd. Hemorojik inme 7,388 kat, HT varlığ 13,326 kat ölüm riski oluşturmaktaydı. Hemorajik inme grubumuzda HT sıklığının daha fazla olmasının prognozu kötüleştirdiğini düşünmekteyiz.

Lipid parametreleri ile inme arasındaki ilişki çeşitli çalışmalarda incelenmiştir ve genel olarak yüksek total kolesterol, LDL kolesterol ve düşük HDL kolesterol düzeyinin artmış iskemik inme riski ile ilişkili olabileceğini öne sürümektedir. Hiperlipidemi damarların intima tabakasinda lipid birikimi sonucu ateroskleroza sebep olmakta, ateroskleroz da inme için zemin oluşturmaktadır. ${ }^{11,20,21}$ Bang ve arkadaşları, kolesterolün damar sistemi üzerinde etkilerinin bilindiğini, normal zar akışkanlığı için gerekli olduğunu ve yeterli kolesterol seviyelerinin damarların bütünlügünü ve yırtılmaya karşı direncini korumak için önemli olabileceğini bildirmiştir. ${ }^{26}$ Iribarren ve ark. yaşlı erkeklerde düşük serum kolesterol seviyesi (özellikle $<178$ $\mathrm{mg} / \mathrm{dL}$ ) ile hemorajik inme arasında pozitif bir ilişki olduğunu bildirmişlerdir. ${ }^{27}$ Dayton ve arkadaşları total kolesterol seviyeleri ve inme riski arasında net bir korelasyon bulunmadığını belirtirmiştir. ${ }^{28}$ Bizim çalışmamızda da hemorajik inme grubunda total kolesterol seviyeleri diğer gruba göre anlamlı düşük bulunmuştur. Yüksek total kolesterol düzeylerinin inme mekanizması üzerindeki etkisi hakkında çalışmalar metadolojik farklılıklar nedeniyle farklı sonuçlar sunmaktadır. Ancak genel olarak bizim çalışmamızda da iskemik inmede total kolesterol seviyesinin hemorajik inmeye göre anlamlı olarak yüksek olması literatür verilerini desteklemektedir.

HDL kolesterol, özellikle kolesterolün periferik dokulardan karaciğere taşınmasında, metabolizmasında ve ateroskleroz gelişme riskinin azaltılmasında önemlidir. 1975 yılında başlatılan Copenhangen City Heart Study çalışmasında
HDL kolesterol düzeyindeki her $1 \mathrm{mmol} / \mathrm{L}$ artışın inme vakalarında \%47’ye kadar azalma sağladığg gösterilmiştir. ${ }^{29}$ Kim ve arkadaşlarının gerçekleştirdiği çalışmada ise HDL kolesterol düzeyi iskemik inmeli hastalarda kontrol grubuna göre düşük bulunmuştur $(\mathrm{p}<0,05){ }^{7}$ Pedro-Botet ve Hachinski, LDL kolesterol seviyeleri ile iskemik inme riski arasında pozitif korelasyon bulmuşlardır. ${ }^{30,31}$

Bizim çalışmamıza benzer nitelikte olan çalışmalar incelendiğinde ise; Pandey ve arkadaşlarının 2016 yılında 162 inme (100 iskemik ve 62 hemorajik), 101 kontrol grubu ile gerçekleştirdikleri çalışmada kontrol grubuna göre inme grubunda (iskemik ve hemorajik toplam) total kolesterol, LDL kolesterol ve trigliserit anlamlı yüksek, HDL kolesterol ise anlamlı düşük bulunmuştur (sırasıyla p: 0,016, p: 0,04, p: 0,001, p: 0,010). Aynı çalışmada, iskemik inme grubunda hemorajik inme grubuna göre total kolesterol, LDL kolesterol, trigliserit ve HDL kolesterol düzeyleri anlamlı yüksek bulunmuştur (sırasıyla p: 0,004, p: 0,005, p: 0,004, p: 0,025, p: 0,001).32 Bharosay ve arkadaşlarının 2013 yılında 90 iskemik inme grubu, 60 hemorajik inme grubu ve 101 sağlıklı kontrol grubu ile gerçekleştirdikleri çalışmada, kontrol grubuna göre inme grubunda (iskemik ve hemorajik toplam) total kolesterol, LDL kolesterol ve trigliserit anlamlı yüksek, HDL kolesterol ise anlamlı düşük bulunmuştur (hepsi için $\mathrm{p}<0,001$ ). Aynı çalışmada, iskemik inme grubunda hemorajik inme grubuna göre total kolesterol, LDL kolesterol ve trigliserit düzeyleri anlamlı yüksek, HDL kolesterol düzeyleri ise anlamlı düşük bulunmuştur (sırasılyla p: 0,000, p: 0,000, p: 0,000, p: 0,025). ${ }^{33}$ Mevcut çalışmamızda ise iskemik inme ve hemorajik inme gruplarımız arasında trigliserit, HDL ve LDL kolesterol açısından anlamlı fark yokken, iskemik inme grubunda total kolesterol seviyeleri hemorajik inme grubuna göre yüksekti ve aradaki fark anlamlıydı. 2019 yılında Rist ve arkadaşlarının 27,937 kadın katılımcıyla gerçekleştirdikleri kohort çalışma, total kolesterol ve HDL kolesterol seviyeleri ile hemorajik inme riski arasında önemli bir ilişki olmadığını, LDL kolesterol seviyeleri için ise $\geq 160 \mathrm{mg} / \mathrm{dL}$ olanlarda, anlamlı olmamakla birlikte, risk artışı olduğu bildirilmiştir. ${ }^{34}$ 
İskemik inme ile kan lipid seviyesesinin İlişkili olduğunu gösteren yayınlar literatürde mevcuttur. ${ }^{27-29,35}$ Ancak prognoz ve lipid parametreleri arasındaki korelayonun değerlendirildiği çalışmalar daha azdır. Özellikle iskemik inme çalışmalarında total ve LDL kolesterol ile trigliserid seviyesi arasında daha belirgin olmak üzere pozitif ve HDL kolesterol ile negatif korelasyon olduğu görülmüştür. Ancak bazı çalışmalar ise bu ilişkiyi desteklememektedir. ${ }^{36,37}$ Bizim çalışmamızda ise iskemik inme ve hemorajik inme grubunda trigliserit ve HDL arasında negatif korelasyon, total kolesterol ve LDL arasında ise kuvvetli pozitif korelasyon görülmüştür. Çalışma sonuçları arasındaki farklılıkların hasta sayıları, altta yatan risk faktörleri ve genetik farklılıklardan kaynaklanabileceğini düşünmekteyiz.

Sonuç olarak, inme alt tipi olarak hemorajik inme varlığ1 ve başvuruda hipertansiyon hastalığı bulunması artmış mortalite riski ile ilişklidir. İskemik inme hastalarında total kolesterol seviyesi hemorajik inmeye göre daha yüksektir. Hipertansiyon sıklığı hemorajik inme hastalarında iskemik inmeye göre daha fazladır. Mortal seyreden iskemik ve hemorajik inme hastalarında trigliserid ve total kolesterol düzeyi taburcu olan hastalara göre anlamlı olarak daha düşüktür. Bu nedenle inme hastalarının başvurudaki trigliserid ve total kolesterol düzeyi hastane içi mortaliteyi öngören bir belirteç olabilir. Ancak mortal seyreden iskemik ve hemorajik inme hastaları ayrı ayrı karşılaştırıldığında gruplar arasında kan lipid parametreleri farkı yoktur. Bunun klinik olarak önemli bir etkiye yol açıp açmadığını belirlemek için bulgularımızın, örneklem büyüklügünün genişletilerek doğrulanması gerekmektedir.

\section{Çalışmanın kısıtlılıkları}

Çalışma tek merkez, retrospektif ve kesitsel bir çalışmadır. Çalışmamızda hastalarda klinik dizabilite durumu ve iskemik alan volümü gibi alt parametlere göre gruplandırma yapılmamıştır. Pirimer sonlanım noktası exitus ve taburculuk olarak alınmıştır. Hastalarda uzun dönem mortalite ve dizabilite durumu ile lipid seviyeleri arasındaki ilişki belirlenmemiştir. Hastalarin başvuru saati, kanların inme- den kaç saat sonra alındığı ve inme süresi ile lipid değerleri arasındaki ilişki değerlendirilmemiştir. Hastaların beslenme özellikleri, fiziksel aktivite durumu, boy-kilo ve vücut kitle indeksine göre karşılaştırma yapılmamıştır. Kan lipid seviyesi hastalar ilk hastaneye yattığı günün ertesinde alınmıştır. Tekrar kontrol değerleri, takip sürecindeki seviye değişikleri ve prognoza etkileri değerlendirilmemiştir.

Çalışma için KTO Karatay Üniversitesi, Tıp Fakültesi İlaç ve Tıbbi Cihaz Dışı Araştırmalar Etik Kurul Başkanlığı'ndan onay alınmıştır (Sayı: 2020/009, Tarih: 15.12.2020). 


\section{Sakarya Tip Dergisi 2021;11(2):400-408}

\section{Kaynaklar}

1. Evci ED, Memis S, Ergin F, Beser E: A population-based study on awareness of stroke in Turkey. Eur J Neurol 2007;14:517-522.

2. Rowland LP, Pedley TA. Serebrovasküler hastalı̆ın patogenezi, sinıflandırlması ve epidemiyolojisi. Doğu O (Çeviri Ed.). Merritt’s Neurology Türkçe 12. Baskı. ss.250-263, Güneș Tip Kitabevleri, İstanbul, Türkiye, 2012.

3. Efstathiou SP, Tsioulos DI, Zacharos ID, Tsiakou AG, Mitromaras AG, Mastorantonakis $S E$, et al. A new classification tool for clinical differentiation between haemorrhagic and ischaemic stroke. J Intern Med 2002;252:121-129.

4. Roger VL, Go AS, Lloyd-Jones DM, Adams RJ, Berry JD, Brown TM, et al. Heart disease and stroke statistics 2011 update: A report from the American Heart Association. Circulation 2011;123(4):18-209.

5. Özdemir G, Özkan S, Uzuner N, Mzdenir AÖ, Gücünyener D. Türkiye'de beyin damar hastalkları için major risk faktörleri. Türk Çok Merkezli Strok Çalıșması. Türk Beyin Damar Hastalkları Dergisi 2000; 2: 31-35.)

6. Ferket BS, van Kempen BJ, Wieberdink RG, Steyerberg EW, Koudstaal PJ, Hofman A, et al. Separate prediction of intracerebral hemorrhage and ischemic stroke. Neurology. 2014;20;82(20):1804-1812.

7. Kim BJ \& Kim JS. Ischemic stroke subtype classification: an Asian viewpoint. J Stroke. 2014:16(1); 8-14.

8. Sacco S, Marini C, Toni D, Olivieri L, Carolei A. Incidence and 10-year survival of intracerebral hemorrhage in a population-based registry. Stroke. 2009;40(2):394-399.

9. Wolf ME, Alonso A, Ebert AD, Szabo K, Chatzikonstantinou A. Etiologic and clinical characterization of patients with recurrent spontaneous intracerebral hemorrhage. Eur Neurol. 2016;76:295-301.

10. Powers WJ, Rabinstein AA, Ackerson T, Adeoye OM, Bambakidis NC, Becker K, et al. 2018 guidelines for the early management of patients with acute ischemic stroke: a guideline for healthcare professionals from the American Heart Association/American Stroke Association. Stroke. 2018;49(3):e46-e110

11. Rist PM, Buring JE, Ridker PM, Kase CS, Kurth T, Rexrode KM. Lipid levels and the risk of hemorrhagic stroke among woman. Neurology. 2019;92:2286-2294.

12. Shadi Y, Elkind MSV. Lipids and cerebrovascular disease: Research and practice. Stroke. 2015;46(11):3322-3328.

13. Utku U, Çelik Y. İnmede etyoloji, sınıflandırma ve risk faktörleri. Serebrovasküler Hastalılar. Balkan S (Ed.). 3th ed. Ankara, Güneș Kitabevi 2009, 85-96.

14. Howard VJ, Cushman M, Pulley L, Gomez CR, Go RC, Prineas RJ, et al. The reasons for geographic and racial differences in stroke study: Objectives and design. Neuroepidemiology. 2005; 25:135-143.

15. Kurth T, Kase CS, Berger K, Gaziano JM, Cook NR, Buring JE. Smoking and risk of hemorrhagic stroke in women. Stroke 2003;34: 2792-2795.

16. Tziomalos K, Spanou M, Bouziana SD, Papadopoulou M, Kostaki S, Dourliou V, et al. Type 2 diabetes is associated with a worse functional outcome of ischemic stroke. World J Diabetes 2014; 5: 939-944.

17. Zhang CE, Wong SM, van de Haar HJ, Staals J, Jansen JF, Jeukens CR, et al. Blood-brain barrier leakage is more widespread in patients with cerebral small vessel disease. Neurology. 2017; 88: 426-432.

18. Balkan S, Topçuğlu MA. İnme ve hipertansiyon. T Klin J Neur 2004, 2: 41-47.

19. Eliyahu H, Mizrahi, Shlomo N, Sela BA, Fleissing Y, Arad M, Adunsky A. Furter evidance of interrelation betwen homocysteine and hypertension in stroke patients. A cross sectiniol study IMAJ. 2003;791-794.

20. Glasser SP, Mosher A, Howard G, Banach M. What is the association of lipid levels and incident stroke? Int J Cardiol. 2016;1;220:890-894.
21. Hindy G, Engström G, Larsson SC, Traylor M, Markus H, Melander O, et al. Role of blood lipids in the development of ischemic stroke and its subtypes: A mendelian randomization study. Stroke. 2018;49:820-827.

22. Lu D, Li P, Zhou Y, Xu X, Zhang H, Liu L, et al. Association between serum non-highdensity lipoprotein cholesterol and cognitive impairment in patients with acute ischemic stroke. BMC Neurol. 2016:26;16(1):154.

23. Nam KW, Kwon HM, Jeong HY, Park JH, Kwon H, Jeong SM. High triglyceride/HDL cholesterol ratio is associated with silent brain infarcts in a healthy population. BMC Neurology 2019: 19:147.

24. Kuusisto J, Mykkanen L, Pyorala K, Laakso M. Non-insulin-dependent diabetes and its metabolic control are important predictors of stroke in elderly subjects. Stroke. 1994; 25: 1157- 1164 .

25. Snarska KK, Bachórzewska-Gajewska H, Kapica-Topczewska K, Drozdowski W, Choraży $M$, Kułakowska A, et al. Hyperglycemia and diabetes have different impacts on outcome of ischemic and hemorrhagic stroke. Arch Med Sci. 2017;13(1):100-108.

26. Bang OY, Saver JL, Liebeskind DS, Starkman S, Villablanca P, Salamon N. Cholesterol level and symptomatic hemorrhagic transformation after ischemic stroke thrombolysis. Neurology. 2007;68:737-742.

27. Iribarren C, Jacobs DR, Sadler M, Claxton AJ, Sidney S. Low total serum cholesterol and intracerebral hemorrhagic stroke: is the association confined to elderly men? The Kaiser Permanente Medical Care Program. Stroke. 1996;27(11):1993-1998.

28. Dayton S, Chapman JM, Pearce ML, Popjak GJ. Cholesterol, atherosclerosis, ischemic heart disease, and stroke. Ann Intern Med. 1970;72:97-109.

29. Appleyard M, Hansen AT, Schnohr P, Jensen G, Nyboe J. The Copenhagen City Heart Study Øster-broundersøgelsen. A book of tables with data from the first examination (1976-78) and a five year follow-up (1981-83). Scand J SocMed. 1989;170(41):1-160.

30. Hachinski V, Graffagnino C, Beaudry M, Bernier G, Buck C, Donner A, et al. Lipids and stroke: a paradox resolved. Arch Neurol 1996; 53(4): 303-308.

31. Pedro-Botet J, Senti M, Nogues X, Rubies-Prat J, Roquer J, D'Olhaberriague L, et al. Lipoprotein and apolipoprotein profile in men with ischemic stroke. Role of lipoprotein (a), triglyceride-rich lipoproteins, and apolipoprotein E polymorphism. Stroke 1992; 23(11): 1556-1562.

32. Pandey A, Shrivastava A, Solanki A. Study of atherogenic lipid profile, high sensitive C-reactive protein neurological deficit and short-term outcome in stroke subtypes. Iran J Neurol. 2016:6;15(3):146-152.

33. Bharosay A, Bharosay VV, Bandyopadhyay D, Sodani A, Varma M, Baruah H. Effect of lipid profile upon prognosis in ischemic and haemorrhagic cerebrovascular stroke. Indian J Clin Biochem 2014;29(3):372-376

34. Rist PM, Buring JE, Ridker PM, Kase CS, Kurth T, Rexrode KM. Lipid levels and the risk of hemorrhagic stroke among women. Neurology 2019;92(19):2286-2294.

35. Kotan D, Yilikoglu Y, Kizlltunç A, Ulvi H, Aygül R, Yanmaz V. Serum adinopektin düzeylerinin iskemik inmedeki rolü. Sakarya Tip Dergisi 2013;3(2):80-84.

36. Papademetriou V, Narayan P, Rubins H, Collins D, Robins S. Influence of risk factors on peripheral and cerebrovascular disease in men with coronary artery disease, low high-density lipoprotein cholesterol levels, and desirable low-density lipoprotein cholesterol levels. HIT Investigators. Department of Veterans Affairs HDL Intervention Trial. Am Heart J 1998; 136:734-740

37. Barter PJ, Connor WE. The transport of triglyceride in the high-density lipoproteins of human plasma. J Lab Clin Med 1975;85(2):260-72. 